\title{
PERANAN MANAJEMEN BOARDING SCHOOL DALAM MENINGKATKAN PRESTASI BELAJAR PENDIDIKAN AGAMA ISLAM
}

\author{
Mursyid Fikri $^{1}$, Ferdinan ${ }^{2}$ \\ ${ }^{* 1}$ Pendidikan Agama Islam Fakultas Agama Islam| Unismuh Makassar \\ ${ }^{* 2}$ Pendidikan Agama Islam Fakultas Agama Islam| Unismuh Makassar
}

\begin{abstract}
ABSTRAK
Jenis Penelitian ini merupakan penelitian kualitatif, Dalam penelitian ini digunakan dua jenis sumber data, yakni data primer dan data sekunder, Pengumpulan data dilakukan dengan teknik observasi (pengamatan), dokumentasi dan wawancara. Hasil penelitian ini menjelaskan bahwa: pertama, manajemen boarding school di SMAN 5 Unggulan Parepare mencakup manajemen komponen-komponen sekolah yang mengatur berbagai jadwal kegiatan, peraturan, fasilitas, sarana prasarana yang dapat membantu memotivasi siswa boarding school untuk belajar dan meningkatkan prestasi mereka baik prestasi akademik maupun prestasi non akademik melalui pembinaan kurikuler yakni pelajaran formal dan pembinaan prestasi unggulan, serta pembinaan ektrakurikuler yakni pengembangan organisasi, pengembangan diri dan pembinaan imtaq. Kedua: Prestasi belajar PAI siswa SMAN 5 Unggulan Parepare tergolong sangat baik di karenakan keseluruhan perolehan hasil belajar siswa pada mata pelajaran PAI melebihi KKM yang telah ditetapkan dan senantiasa mengalami peningkatan setiap semesternya. Ketiga: Prestasi belajar PAI siswa dalam hal ini program pembinaan imtaq yakni kultum, ta'lim, pengajian rutin, tilawah, pengembangan baca tulis al-quran dan pengajian hari-hari besar Islam.
\end{abstract}

\section{Kata Kunci : Manajemen, Boarding School, Prestasi PAI}

\begin{abstract}
This research is a qualitative research. In this research, there are two types of data sources, namely primary data and secondary data. Data collection is done by observation, documentation and interview. The results of this study explain that: firstly, the management of boarding school in SMAN 5 Unggulan Pare-pare includes the management of school components that organize various activity schedules, regulations, facilities, infrastructure that can help motivate boarding school students to learn and improve their achievement in both academic achievement As well as non-academic achievement through curricular coaching that is formal lesson and guidance of superior achievement, as well as extracurricular development that is organization development, self-development and faith and piety development. Second: Learning achievement of PAI students of SMAN 5 Unggulan Pare-pare classified very well in because the overall acquisition of student learning outcomes on the subjects of PAI exceeds the established KKM and always increase each semester. Third:improve student achievement PAI students in this faith and piety coaching program that is speech, ta'lim, recitation routine, recitations, development of reading al-quran and recitation days of Islam.
\end{abstract}

Keywords: Management, Boarding School, Achievement of PAI 


\section{PENDAHULUAN}

Pendidikan merupakan hal yang terpenting dalam menjalankan roda kehidupan bernegara begitu pula halnya dengan pendidikan agama yang merupakan bagian integral dari system pendidikan nasional, dalam undangundang No. 20 tahun 2003, BAB 1 pasal 37 ayat (1) tentang system pendidikan nasional:

Pendidikan nasional berfungsi mengembangkan kemampuan dan membentuk watak serta peradaban bangsa yang bermartabat dalam rangka mencerdaskan kehidupan bangsa, bertujuan untuk berkembangnya potensi peserta didik agar menjadi manusia yang beriman dan bertaqwa kepada tuhan yang mahaEsa, berakhlak mulia, sehat, berilmu cakap, kreatif, mandiri, dan menjadi warga negara yang demokratis serta beratanggung jawab.

Perkembangan potensi yang dimiliki peserta didik dapat terwujud dengan baik melalui perantara sekolahsekolah pada umumnya dinegeri ini. Sekolah merupakan suatu lembaga pendidkan yang sengaja dirancang dan harus dilaksanakan sesuai aturanaturan yang ketat, seperti harus berjenjang dan berkesinambungan, sehingga disebut pendidikan formal. Sekolah merupakan suatu lembaga khusus, suatu wahana dan suatu tempat untuk menyelenggarakan pendidikan yang didalamnya terdapat suatu proses belajar mengajar untuk mencapai tujuan pendidikan tertentu. Pendidikan

disekolah merupakan proses

pembelajaran dimana terdapat

serangkaian kegiatan yang

memungkinkan terjadinya perubahan

struktur atau pola tingkah laku seseorang dalam kemampuan kognitif, afektif, dan psikomotorik yang selaras, seimbang dan bersama-sama turut serta meningkatkan kesejahtraan sosial. Sedangkan belajar bertujuan untuk merubah tingkah laku manusia sekaligus menambah wawasan manusia dari belum tau menjadi tau dan dari tau menjadi lebih tau, proses belajar ini juga terjadi apabila terdapat interaksi antara seseorang dan lingkungannya. Oleh sebab itu belajar dapat terjadi kapan dan dimanapun saja.

Sekolah harus juga bisa mendukung dan memfasilitasi segala aktifitas peserta didik dalam rangka meningkatkan segala potensi yang dimiliki oleh peserta didik sehingga dapat meningkatkan prestasi para siswa tersebut. Apalagi di zaman yang serba moderen ini sekolah dituntut untuk mengarahkan peserta didik untuk menghindari segala bentuk patologi sosial yang terdapat dikalangan masyarakat saat ini, seperti meluasnya Peredaran obat terlarang, narkotika, pergaulan bebas, tawuran remaja dan lain-lain. Sehingga menumbuhkan kekhawatiran pada orang tua peserta didik tersebut. Ditambah globalisasi di bidang budaya, etika dan moral yang didukung oleh perkembangan 
teknologi dan transfortasi maka tak jarang itu menjadi bumerang tersendiri terhadap perkembangan tingkah laku dan keperibadian peserta didik. Bagi anak yang tidak dapat memanfaatkan perkembangan dunia dengan baik dan benar maka akan mengantarkan mereka pada perilaku yang menyimpang dari agama dan mengakibatkan krisis moral pada anak bangsa. Tentu hal tersebut sudah menjadi kekhawatiran bagi setiap orang tua peserta didik.

Setiap orang tua tentunya mencintai anak-anaknya sehingga mereka menginkan agar anaknya kelak mampu menjadi orang yang bahagia dalam mengarungi hidup dengan pilihan hidup yang terbaik. Termasuk juga dalam memilih tempat pendidikan untuk anak, orang tua akan mencaricari informasi sebanyak mungkin mengenai sekolah-sekolah yang unggul agar anak tidak salah pilih dan terjerumus pada pilihan yang salah. Hal seperti ini merupakan fitrah dan naluri semua orang tua.

Selain orang tua, masyarakat sebagai stoke holder juga selalu berharap agar anak yang dititipkan ke sekolah dapat memenuhi harapan yang diinginkan. Harapan masyarakat yang dimaksud antara lain adalah agar anak mereka menjadi anak yang rajin ibadah dan berakhlakul karimah, cerdas, terampil, cinta ilmu dan cinta kemajuan. Berbagai harapan dari orang tua dan stok holder tersebut menjadi tantangan bagi sekolahsekolah untuk terus meningkatkan mutu pelayanan guna menarik minat para orang tua dan siswa untuk memilih sekolah tersebut. Sebab lembaga pendidikan sebagai instrumen paling utama dalam menyiapkan sumber daya manusia dituntut mampu menyediakan kualitas sumber daya yang handal.

Melihat begitu banyaknya tantangan yang di hadapi dunia pendidikan di era globalisasi sekarang ini baik tantangan internal maupun eksternal mengharuskan kita siap menghadapi tantangan tersebut dengan langkah-langkah cerdas, aplikatif, dan visioner.

Oleh sebab itu untuk menjawab kekhawatiran serta harapan orang tua tersebut, kini telah banyak bermunculan sistem pendidikan unggulan berasrama (boarding school). Pendidikan berpola asrama ini sesungguhnya merupakan perpaduan sistem pendidikan sekolah umum dengan sistem pendidikan pesantren dimana siswa mendapatakn pendidikan dan pengajaran selama 24 jam. Model pendidikan ini menawarkan keunggulan yang diukur dari sisi kesiapan peserta didiknya menjadi insan yang beriman dan bertaqwa, serta mampu hidup mandiri dalam masyarakat.

Keberhasilan suatu sekolah dalam menjalankan segala aktifitas pembelajaran ditentukan oleh beberapa faktor pendukung. salah satu faktor tersebut adalah faktor manajemen yang diselenggarakan oleh sekolah. Karena manajemen merupakan unsur penting 
dalam pelaksanaan setiap program organisir kegiatan sekolah. Berdasarkan uraian latar belakang di atas, penulis merumusakan masalah sebagai berikut:

1. Bagaimana pelaksanaan manajemen Boarding School SMAN 5 Unggulan Parepare?

2. Bagaimana prestasi belajar PAI siswa SMAN 5 Unggulan Parepare?

3. Bagaimana peranan manajemen Boarding School dalam meningkatkan prestasi belajar PAI siswa SMAN 5 Unggulan Parepare?

\section{METODE PENELITIAN}

Jenis penelitian ini merupakan jenis penelitian lapangan (field research) yakni di SMAN 5 Unggulan Parepare dengan pendekatan kualitatif yaitu penelitian yang bermaksud untuk mendepenelitiankan dan menganalisis fenomena, peristiwa, aktifitas sosial, sikap, kepercayaan, presepsi, pemikiran dan seseorang secara individu maupun kelompok beberapa dipenelitian digunakan untuk menemukan prinsip-prinsip dan penjelasan yang mengarah pada kesimpulan.

Penelitian ini dilakukan dengan menggunakan metode penelitian kualitatif karena penelitian kualitatif mempunyai dua tujuan yakni : pertama, menggambarkan dan mengungkapkan (to describe and explore), kedua, menggambarkan dan menjelaskan (to describe and explain).

Penelitian ini bertujuan untuk mendepenelitiankan tentang peranan manajemen boarding school dan menggambarkan bagaimana sekolah boarding school sebagai upaya dalam meningkatkan prestasi belajar PAI siswa SMAN 5 Unggulan Parepare. Dalam penelitian ini digunakan dua jenis sumber data, yakni data primer dan data sekunder Adapun tekhnik pengumpulan data yang digunakan adalah Dokumentasi, Observasi (Indepth interview) dan Wawancara. Responden yang penulis interview adalah guru bidang studi Pendidikan Agama Islam, pembina Imtaq dan beberapa dari perwakilan siswa di setiap tingkatan kelas SMAN 5 Unggulan Parepare.

\section{HASIL PENELITIAN DAN PEMBAHASAN}

\section{A. Pelaksanaan Manajamen Boarding School SMAN 5 Unggulan Parepare}

Salah satu keunggulan yang terdapat pada model pendidikan boarding school adalah kegiatan peserta didik yang padat serta terjadwal dalam rangka membentuk karakter dan pengetahuan peserta didk. Jadi ketika memutuskan untuk masuk ke sekolah ini semua siswa sudah di tetapkan jadwalnya sedemikian rupa sehingga terjadi keseimbangan antara kegiatan sekolah dan kegiatan asrama. 
Kegiatan yang di tawarkan sekolah secara garis besar di bedakan menjadi dua, yaitu kegiatan sekolah formal (kurikuler) dan kegiatan keasrama-an (ekstrakulikuler).

\section{Program Kurikuler}

Program kurikuler merupakan program yang sudah dijadwalkan oleh pihak sekolah yang harus diikuti oleh semua siswa sehingga aktifitas mereka jadwalnya sudah diatur dan didesaign oleh sekolah. Adapun kurikulum yang digunakan di SMAN 5 Unggulan Parepare adalah kurikulum 2013.

Kegiatan Kurikuler ini berlangsung setiap hari selain hari minggu. Di mulai pada pukul 07.00 sampai 15.00 pembelajaran formal kemudian dilanjutkan dengan pembinaan prestasi unggulan terkait Mata pelajaran ujian Nasional dan OSN pukul 16.00 sampai 17.30 sore dan 20.00 sampai 21.30 malam setiap hari senin sampai kamis.

\section{Program ekstrakurikuler}

$\begin{array}{cccc} & \text { Selain } & \text { program } & \text { kurikuler } \\ \text { SMAN } & 5 & \text { unggulan } & \text { Parepare }\end{array}$ mempunyai program ekstrakurikuler yang berkonsentrasi untuk mengembangkan bakat serta kompetensi yang dimiliki oleh peserta didik. Kegiatan ekstrakurikuler ini terbagi atas 3 yakni pengembangan organisasi siswa, pengembangan diri siswa dan pengembangan IMTAQ
Adapun peneliti melakukan wawancara kepada bapak fadly hayya S.Pd.I selaku pembina imtaq yang mengatakan bahwa :

Pembinaan imtaq di lingkungan boarding school memiliki banyak manfaat, dan pembinaan dilakukan setiap ba'da magrib dan ba'da subuh setiap harinya, dengan tujuan menambah wawasan serta pengetahuan siswa mengenai islam baik dari segi pengetahuan mengenai agama dan terlebih bada pengetahuan mengenai cara baca al'quran dengan baik dan benar (hukum tajwid), dan tak jarang kami memerlakukan diskusi agama yang temanya seputar permasalahanpermasalahan fiqh, muamalah dan ibadah agar siswa mampu menilai dan memilih antara mana amalan yang shohih dan amalan-amalan yang dhoif.

\section{B. Prestasi Belajar PAI Siswa SMAN 5 Unggulan Parepare}

Prestasi belajar Pendidikan Agama Islam merupakan hasil yang dicapai oleh peserta didik dalam menguasai atau menerima materi di dalam pembelajaran pendidikan agama Islam, prestasi peserta didik dikatakan baik ketika secara keseluruhan melebihi dari KKM mata pelajaran yang di tetapkan serta mengalami peningkatan dari setiap semesternya.

Adapun prestasi belajar PAI siswa SMAN 5 unggulan parepare tergolong sangat baik karena mampu 
melebihi dari KKM yang di tetapkan dan senantiasa mengalami peningkatan setiap semesternya sebagaimana dari keterangan guru mata pelajaran PAI kelas XII bapak Fadly Hayya S.Pd.I dari wawancara peneliti yang mengatakan bahwa :

Secara keseluruhan prestasi belajar PAI siswa dikelas XII senantiasa mengalami peningkatan dari setiap semesternya, dan terkhusus nilai kelas XII semester ganjil yang lalu rata-rata siswa mendapatkan nilai $>90$ dan bahkan yang tertinggi mencapai nilai 98. Siswa kelas XII rata-rata telah menguasai pelajaran tajwid sehingga memudah-kannya dalam mengua-sai tafsir dan makna ayatperayat dari setiap bab mata pelajaran PAI.

Prestasi dapat dilihat dari seberapa besar pemahaman serta pengetahuan yang di miliki peserta didik terkait pengetahuan agama Islam yang dimilikinya dan berdasarkan wawancara dari beberapa siswa yang menjelaskan bahwa pengetahuan agama yang dimilikinya sebelum dan selama berada di SMAN 5 unggulan Parepare sangatlah berbeda, mereka merasakan perubahan yang begitu significant bukan hanya dari pengetahuan agama yang mereka miliki namun juga terlebih pada pengamalan agama serta kewajiban melaksanakan syariat islam. Sebagaimana keterangan beberapa siswa yang peneliti wawancara.

Hal itu membuktikan bahwa siswa merasakan perbedaan dari segi pengetahuan agama sebelum dan selama bersekolah di SMAN 5 unggulan Parepare dan bahkan dari segi pengamalan agamapun mereka merasakan perbedaan yang sangat significant.

\section{Peranan Manajemen Boarding School dalam Meningkatkan Prestasi Belajar PAI Siswa SMAN 5 Unggulan Parepare}

Keberhasilan sebuah lembaga pendidikan dilihat dari baik buruknya prestasi belajar yang didapatkan oleh peserta didiknya dan baik buruknya prestasi belajar peserta didik sangat ditentukan dari manajemen suatu lembaga pendidikan dalam memberikan fasilitas pendidikan kepada peserta didik. Terkhusus sekolah yang bersistem boarding school pemanfaatan waktu serta manajamen pendidikan sangat menentukan kualitas dan prestasi belajar peserta didiknya dikarenakan sekolah bertanggung jawab penuh 24 jam terhadap kegiatan serta aktifitas keseharian peserta didik.

Manajamen Boarding School dalam hal ini Manajamen pembinaan imtaq memiliki peranan dalam meningkatkan prestasi belajar PAI siswa SMAN 5 Unggulan parepare, siswa merasakan manfaat yang begitu besar terhadap program pembinaan imtaq dikarenakan materi-materi yang di dapatkan disaat proses pembinaan imtaq memiliki keterkaitan dengan materi bidang studi Pendidikan Agama Islam sehingga membantu 
memudahkan siswa dalam menguasai materi pelajaran Pendidikan Agama Islam di kelas. Bukan hanya itu siswa merasakan perubahan dari segi pembacaan ayat suci al-quran dengan baik dan benar dan itu memudahkan mereka dalam menguasai pelajaran tajwid di kelas. Sebagaimana hasil dari wawancara kepada saudra Hasbia basri siswa kelas XII mengatakan bahwa :

Kami merasakan pembinaan imtaq memiliki peran yang begitu besar terhadap pelajaran agama Islam, karena pada dasarnya materimateri yang kami dapatkan dalam pembinaan imtaq sangat besar sangkut pautnya dengan pelajaran Pendidikan Agama Islam.

Pembinaan imtaq tidak hanya berpengaruh pada peningkatan prestasi belajar peserta didik melainkan dapat menambah rasa percaya diri dan motivasi belajar peserta didik dalam mengikuti pelajaran Pendidikan agam islam. Hal ini di rasakan oleh saudara Muhammad Nur Ikhwan siswa kelas X mengatakan bahwa :

Pembinaan imtaq sangat kami rasakan manfaatnya, karena berkat pembinaan imtaq itu mampu menambah rasa percaya diri dan menambah wawasan kami, terutama ketika topik diskusi dikelas sudah kami dapatkan disaat diskusi agama di proses pembinaan imtaq maka ini menambah percaya diri kami untuk aktif dalam berdiskusi dikelas.

Lanjut berdasarkan wawancara dari saudra Siti Ihza Arsela Kasim siswa kelas XI mengatakan bahwa :
Peranan pembinaan imtaq sangat bermanfaat terhadap prestasi belajar saya, seperti dalam pembinaan imtaq kami sering diceramhkan berbagai hal dan berbagai tema tertentu, sehingga pada saat proses belajar-mengajar dimulai. Saya diajak untuk berdiskusi mengenai suatu tema dan kebetulan tema tersebut telah disinggung saat pembinaan imtaq, sehingga saya yang telah mempelajarinya di pembinaan imtaq tidak tabu, tidak canggung lagi ketika berdiskusi, sehingga sayapun lebih percaya diri dalam diskusi.

Manajemen pembinaan imtaq di SMAN 5 unggulan Parepare dirancang oleh pembina imtaq agar mampu melatih kedisiplinan dan kepercayaan diri peserta didik dalam mengikuti pelajaran Pendidikan agama Islam namun bukan hanya itu melalui proses pembinaan imtaq di harapkan peserta didik mampu mnegamalkan segala ilmu yang didapatkan dan tercermin dari praktek keagamaan yang dilakukan oleh peserta didik sehari-hari, baik dari segi kewajiban menjalankan shalat lima waktu dan sunah-sunnah rawatib maupun puasa sunnah senin dan kamis. Sebagaiman hasil wawancara dengan Guru mata pelajaran PAI sekaligus penanggung jawab pembinaan Imtaq SMAN 5 unggulan Parepare bapak Fadly hayya S.Pd.I mengatakan bahwa :

Manajamen pembinaan imtaq sangat berpengaruh terhadap peningkatan prsetasi belajar peserta didik. Hal ini dikarenakan 
melalui pembinaan ini mampu meningkatkan kedisiplinan dalam proses PBM dan praktek keagamaan/ spritual yakni melalui pembiasaan ibadah ritual shalat lima waktu berjamaah, shalat Dhua, puasa senin kamis, kultum dan ibadah-ibadah sunnah lainnya.

Hal ini ini dirasakan oleh siswa bahwa melalui proses pembinaan imtaq mampu menambah semangat siswa dalam beribadah terutama melaksanakan kewajiban shalat lima waktu, sebagaimna wawancara yang peneliti lakukan dengan saudra Yulia Nugra siswa kelas $\mathrm{X}$ mengatakan bahwa :

Dengan adanya pembinaan imtaq, tentu menambah pengetahuan islam yang saya miliki, selain itu pembinaan imtaq juga meningkatkan semangat saya untuk meningkatkan frekuensi beribadah. Serta mampu membuat saya disiplin dalam mengikuti PBM dikelas. Dan juga melalui pengajian rutin pada proses pembinaan imtaq tentu menambah atau melatih skill saya dalam melafalkan al-quran pada proses PBM.

\section{Berdasarkan}

keterangan

beberapa responden diatas mereka merasakan manfaat yang begitu besar melalui proses manajemen pembinaan imtaq sehingga mampu memudahkan dan menambah kepercayaan diri peserta didik dalam mengikuti proses belajar mengajar di dalam kelas sehingga berpengaruh terhadap peningkatan prestasi belajar PAI peserta didik.

\section{KESIMPULAN}

Berdasarkan hasil penelitian yang telah disajikan pada bagian terdahulu, jawaban atas permasalahan yang diangkat dalam penelitian ini, maka berikut ini penulis mengemukakan beberapa hal pokok yang merupakan kesimpilan yaitu:

1. Manajemen boarding school yang diterapkan di SMAN 5 Unggulan Parepare tergolong sangat baik dalam rangka mengembangkan potensi serta pengetahuan peserta didik, mulai dari manajemen program kurikuler yakni PBM yang begitu padat hingga manajeman program ekstrakurikuler yang bertujuan mengembangkan berbagai potensi peserta didik baik potensi organisasi, pengembangan diri serta pengetahuan agama peserta didik melalui proses manajemen pembinaan imtaq.

2. Prestasi belajar PAI siswa SMAN 5 Unggulan Parepare dapat dikatakan sangat baik karena secara keseluruhan prestasi yang diperoleh peserta didik telah melebihi KKM mata pelajaran Pendidikan Agama Islam yakni 87 perolehan nilai terendah serta 98 perolehan nilai maksimal dan dari grafik perolehan prestasi belajar siswa mengalami peningkatan setiap semester.

3. Manajamen boarding school SMAN 5 Unggulan Parepare sangat berperan dalam meningkatkan prestasi belajar PAI peserta didik terutama program manajemen 
pembinaan imtaq yang di terapkan di sekolah tersebut yakni program Kultum, ta'lim, pengajian rutin, tilawah serta pengembangan baca tulis al-quran dan pengajian harihari besar Islam.

\section{DAFTAR PUSTAKA}

Abdullah, Abdurrahman, salah. 1994. Teori-teori Pendidikan

Berdasarkan Al-quran. Jakarta: Rineka Cipta.

Al-Khalili, Abdussalam, Amal. 2005. Mengembangkan Kreativitas Anak. Jakarta: Pustaka AlKautsar.

Arief, Armai. 2000. Pengantar Ilmu Pendidikan Islam. Jakarta: Ciputat Press.

Arifin M. 1991. Ilmu Pendidikan Islam. Jakarta: Bumi Aksara.

Arifin M. 1994. Ilmu Pendidikan Islam Suatu Tinjauan Teoritis dan Praktis Berdasarkan Pendidikan Interdisipliner. Jakarta: Bumi Aksara.

Arikunto, Suharsimi. 1990. Manajemen Pengajaran Secara Manusiawi. Jakarta: PT. Rineka Cipta.

Aziz, Abdul, Shaleh dan Abdul aziz Abdul Majid. At-tarbiyah $W a$ Thuruqut Tadris. Mesir: Darul Ma'arif.

Departemen Pendidikan dan

Kebudayaan. 1992. Kamus Besar Bahasa Indonesia. Jakarta: Balai Pustaka.
Djamas, Nurhayati. 2009. Dinamika Pendidikan Islam di Indonesia Pascakemerdekaan.Jakarta: PT Raja Grapindo.

Echols M. John, Hasan Shadli. 1996. An English-Indonesian. Jakarta: Gramedia.

Harjaningrum, tri, Agnes, et.al. 2007. Peranan Orang Tua dan Praktisi Dalam Membantu Tumbuh Kembang Anak Berbakat Melalui Pemahaman Teori dan Tren Pendidikan. Jakarta: Prenada.

Khumairah Mira. 2013. Pembinaan Akhlak Siswa Melalui Program Boarding School. LTA S.1 Kearsipan Fakultas Ilmu Tarbiyah dan Keguruan, UIN Syarif Hidayatullah

Maergon T. Clifford. 1971. introduction to Phychology, sixth edition. New York: Mc GrawHill international Book Company.

Maimun, Agus dan Agus, Zainul, Fitri. 2010 . Madrasah Unggulan (Lemabaga Pendidikan Alternatif di Era Komfetitif). Malang, UIN Maliki Press.

Majid, Abdul \& Dian Andayani. 2004. Pendidikan Agama Islam Berbasis Kompetensi, Konsep Dan Implementasi Kurikulum 2004. Bandung: PT Remaja. Rosdakarya.

Maknun, Jonar. Pengembangan Sekolah Menengah Kejuruan (Smk), Boarding School Berbasis 
Keunggulan Lokal. Pdf, JPTA FPTK UPI.

Nawawi, Hadari. 2011. Metode

Penelitian Bidang Sosial.

(Yogyakarta: Gadjah Mada

University Press.

Porwodarminto. WJS. 2007. Kamus

Besar Bahasa Indonesia.

Jakarta: Balai Pustaka.

Prastowo, Andi. 2011. Metode

Penelitian Kualitatif dalam

Prespektif Rancangan

Penelitian. Jogjakarta: Ar-ruz media.

Putro, Zarkasyi, Khamin. 2005. Orang

Tua Sahabat Anak dan Remaja.

Yogyakarta: Cerdas Pustaka.

Syah, Muhibbin. 2000. Psikologi

Pendidikan dengan Pendekatan

Baru. Cet V. Bandung: PT

Remaja Rosdaka. 